\title{
SELF-MANAGING SOCIALISM AND URBAN PLANNING: THE CASE STUDY OF GENERAL PLAN OF BELGRADE 1972
}

\section{A B S T R A C T}

This paper aims to open up a discussion about relations between former Yugoslavia's socialism and planning practice resulting from self-managing system established in early 1950s. Although this system was applied through a top-down approach, it implied, at least allegedly, coordination, integration and democratic harmonisation of particular interests with common and general ones on local level. The paper will briefly review the history and concept of socialist ideology and consider the impact that it had on institutional arrangements evolution and planning practice in Serbia. It will then touch on the role of ideology for urban planning process at the local level, understanding self-managing planning principles, their benefits, role and significance in planning practice.

\section{Jelena Radosavljević}




\section{INTRODUCTION}

Since its inception, urban planning has been based on decision-making with various influences on the subject of planning. Social context, i.e. mostly politics, lies at the core of these decisions. This paper brings into question the ideological position of decision-makers and its manifestations in the process of plan making and its contents.

The position of planners in the social context of self-managing socialism is of great importance to us to understand the attitude towards urban planning and urban plan, which was created by politics. This paper examines the connection between planning and individual's needs and interests, which represent a reflection of the "self-managing" principles based on the "bottom-up" approach taken by the government, and on the extent to which an individual, a worker and a citizen as a part of the society could emphasise his/her needs through the plan.

The aforementioned approach taken by the government in constituting the selfmanaging ideology is the basis for the research of the plan from the aspects of communication theory, in which the participants in the planning process head toward the establishment of the concensus. On the other hand, taking into consideration that the planning is directed towards achieving rationality, and that this rationality in planning is based on scientifically-based arguments, one must ask the question to what extent rationality serves as a means for achieving individual, that is, mutual interests. To what extent can we talk about formal, instrumental rationality, which, apart from the scientific facts, includes an intuitive, creative approach from the part of the planner, in opposition to the communicative rationality aimed at the achievement of the concesus, and between whom?

This analysis will hinge on the 1972 General Urban Plan of Belgrade, made while the social progress was in full swing, both on a general and individual level. That was the period of implementation of decentralisation, that is, the period of institutional strengthening of local government units and also the period during which a unique urban law did not exist and during which the relations in self-managing planning were regulated. In the specific ideological surroundings, where the words community, agreement and social ownership are present in all the documents, in the presentation of the plan, to what extent can we talk about the consensus or about a rational choice? 


\section{ON THE IDEOLOGY OF SELF-MANAGEMENT}

The characteristics of modernisation after the Second World War include the aim for technological and economic development, based on the intensive promotion of the new Yugoslav socio-economical concept: socialist self-management. ${ }^{1}$ The socialist construction of the new society, at the beginning, required changes in the economic activities, the achievement of the particular level of professional and qualificational status of an individual, the establishment and institutionalisation of the system of social relations, as well as changes in the general view of the world and society.

The realisation of the five-year plans for social development has stipulated the achievement of a certain level of socio-economic development which has further stimulated horizontal and vertical social mobility and put emphasis on the significance of the general, mutual interest based on the idea of selfmanagement. ${ }^{2}$ In order to understand the process of building up the ideology of self-managing socialism, several segments about the idea of self-management, about the reconsideration the position of an individual as a self-manager and about the construction of discourse of self-managing democracy will be discussed in this paper. Discussing the aforementioned characteristics of the developing context of Yugoslavia and emphasising some of them, in his 1977 book, Edvard Kardelj asks the following question:

"In the age which requires a large amount of means of production, a great internal social centralisation, transnational integration of work and a great mutual dependence of peoples, and in which the degree of integration of the society and the whole humankind is higher than ever, how can an individual's freedom to work and create, and thus his/her freedom to govern the society be provided." ${ }^{\prime 3}$

He further states that:

"The idea and the practice of self-government ... institutionalised selfgovernment in the sense of complex social system, provide, in my opinion, the answer to that question, because they turn an individual's and the people's freedom to create into the incentive to integrate the productive forces and the humankind, and thus that process of integration is conditioned by that freedom. In that sense, the idea and the practice of self-government can undoubtedly influence the further development of the social and democratic system in the world."

Achieving the freedom for an individual to work and create, and thus govern the society through establishing institutionalised self-management as a complex 
social system represents a way to solve the problems which Kardelj mentions in his book. Therefore, we can wonder how the relations between the citizens and institutions which build self-management are created, that is, how can we even talk about "freedom" and about an individual who "governs" the society, if institutions are those that carry out and enable that freedom? Analysing the text by Borisav Džuverović, where he enumerates the characteristics of the culture of self-management, in which:

"The basis on which culture is developing lie in self-management...as a way of life...a worker is not only a manual worker, because as soon as he/she starts deciding about the extended reproduction affairs, about the conditions and the goals of the free exchange of work among the certain areas of combined work, and as soon as he/she is, though delegats and delegations, in the position to take part in making decisions about the mutual interests on different levels of the joint work and the society, in that case, his/her work is no longer manual, but mental."

In his paper An Individual as a Political Citizen or as a Self-managing Social Being from 1987, Kardelj emphasises that:

"In the development of the system of socialist self-management ... it is characteristic of self-managing democracy to start from an individual as the one who bears the totality of people's partial and general social interests. And it is exactly those interests that connect him/her to other people in the multitude of objectively existing communities of interest, no matter if they are organised as such or they simply exist as an objective social fact."

The government's orientation towards the "bottom-up" approach, which emphasises the role of a citizen in making decisions and governing, that is, the role of an individual as the one who bears individual and general interests in the society, opens a set of questions about the understanding of the complexity of the relations between the ideology of self-management and planning. If we take into account that the plan represented social agreement in self-managing socialism, how is an individual, his needs and interests, included in the process of planning?

\section{SELF-MANAGING SOCIALISM AND PLANNING}

In order to gain a better understanding of the relations between self-management and planning, we deem it necessary to understand the changes in social development and the way of transferring those changes to the framework of 
urban planning. The regulatory framework within which the self-management was developed, was based on the five-year plans of the social development. The Third Social Plan (1961-1965) 7 is of the greatest importance for this paper in the context of understanding the developing tendencies of that time. The plan emphasises the urbanization of cities as the main developing question, as well as the need for larger investments in raising social standards, neglected during the previous period, when the largest investments were directed towards the development of industry. As regards the landscaping and construction of cities, this period is characterised by the construction of residences and their municipal equipping, the foundation of schools, kindergartens, healthcare institutes, cultural centres, and other contents, but also by uneven development, followed by fragmentariness in the making of urban plans, as opposed to the great expectations at the level of the union of all republics.

Apart from the significant changes in social development, it is important to discuss the status of urban planning as a profession and a science, and the attitude towards the trends which were topical during that period at the global level. The first trend is connected to the decentralisation model in urban planning, the second covers the development of cybernetics and its application in planning, which influenced the establishment of rational planning as the best methodological approach to planning, and the third trend included turning to the public participation in planning. ${ }^{8}$ The positioning of planning as a profession and a science in relation to the aforementioned global trends is one of the reasons for the interpretation of the case study from the aspect of the theory of rational choice, as a relation to rational planning. On the other hand, the idea of self-management, that is, the government's aim to raise social standards, as well as the presence of the global trend about including the public in the process of planning, is the reason for the interpretation of the case study from the aspect of communication theory which started developing in the 1970s.

\section{INSTRUMENTAL VS. COMMUNICATIVE RATIONALITY}

The question of rationality has been present in planning since its foundation. According to the traditional understanding of the rational paradigm of planning, the planners were those who were making decisions and building their credibility through the implementation of scientific methods, but relations among the beliefs, statements, and actions may significantly influence the constitution of rationality. ${ }^{9}$ 
In his paper, Ernest Alexander suggests the typology of rationality in relation to the different paradigms of planning, out of which instrumental rationality and communicative rationality are especially important for our paper, while other types of rationality, such as categoric, strategic, dialectic and hermeneutic rationality ${ }^{10}$ will not be analysed. Instrumental rationality is often related to the traditional approach to planning, that is, to rational planning. Starting from the understanding of formal rationality, it is basically defined as drawing conclusions about the acquisition of the adequate meanings and procedures. ${ }^{11}$ Regarding the fact that planning is based on making choices, formal instrumental rationality may make it possible to reach the previously set goals in planning, apart from appraising the possible alternatives. The characteristics of instrumental rationality very often include subjective knowledge and intuitive evaluation, especially imagination and creativity in creating alternative ways of operating which are the subject of analysis and evaluation of decisions. ${ }^{12}$ Such perception of rationality shows the importance of the position of planners and other decision-makers, i.e. the power they have in creating certain decisions. Similarly, Bent Flyvbjerg thinks the power is the one that defines what is considered as rationality, taking into account that the planners are real participants in real political processes. ${ }^{13}$ For that reason, Flyvbjerg thinks that it is necessary to develop an alternative approach to planning, which would accept the power as an inevitable part of the conflict different interests and opinions and he calls it real-life rationality. ${ }^{14}$

The permeation of rationality and power continues also in communication among the participants in the process of planning. Taking into account that there are different participants in the process of planning, from politicians to citizens, the question of rationality is of great importance for communication. In order to understand the positions from which the decision-makers participate in the process of planning, Flyvbjerg and Tim Richardson state that we have to analyse how the communication goes, and how politics, planning and democracy function, emphasising the distinction between Habermas's and Foucault's approach to investigating the role of communication in the process of planning, where Habermas's point of view is directed towards what should be done, and Foucault's to what has already been done. ${ }^{15}$

Habermas's approach is directed towards developing an ideal, democratic society in which rationality would be possible, and represents the result of the consensus set among different participants in the process of making decisions. Foucault, on the other hand, develops an approach in which the question of communication and rationality is seen through the analysis of power, i.e. 
he is concerned with the usage of means for analysing the understanding of power, its relations with rationality and knowledge, and the usage of those analyses in creating changes. ${ }^{16}$ Foucault states that "we should admit that power produces knowledge ... that power and knowledge directly imply one another, that there is no power relation without the correlative constitution of a field of knowledge." ${ }^{17}$ Habermas's approach is oriented towards universal values, towards the independence of context in decision-making, and towards the control established by the Constitution and the development of institutions, while Foucault focuses on the local government units, the dependence of context in making decisions and on the analysis of strategies and tactics which represent the basis for the struggle of power. ${ }^{18}$

In order to present the formation of discourse, this paper will not be focused on the quality of the implemented urban solution, i.e. of the plan, the text will be analysed in more details instead, in a way which should draw attention to the selection of words, as well as to the graphic illustrations applied in the paper - their creation, purpose and significance in argumentation. The point of this analysis is to present the formation of discourse, which for us represents the result of the expression of ideology and power, and to emphasise different insights into how a plan can be read and interpreted.

\section{CASE STUDY - THE 1972 GENERAL PLAN OF BELGRADE}

The creation of the plan was preceded by the decision on the plan revision from 1950, brought about by Belgrade City Council in 1966. The Urban Planning Institute of Belgrade was engaged in the creation of the plan, along with many other institutes which worked on creating studies needed for making the plan. The reasons for the revision of the 1950 plan are organised in three units:

- The first unit puts emphasis on "the growth of the society's economic forces and the development of the socialist self-management system and the immediate decisions of workers, the development of automobiles and tertiary activities, as well as the process of uncontrollable urbanisation outside urban areas." 19

- The second unit emphasises the improvement in the area of urbanism, in the domain of scientific methods and tools, and the availability of data in the development of urban areas. "The fact that the human environment is endangered is gaining importance and it has directly influenced the reconsideration of the old urban criteria and the affirmation of the new ones. ${ }^{20}$ 
- In the third unit, it is stated that: "The old General plan, which included Belgrade's development from 1950 to 1980 , could no longer serve as the basis for making far-reaching decisions on major constructions", as well as that "for the evaluation of the feasibility of major construction and the reconstruction of the urban area, and especially for the right locations and investments in the objects of infrastructure", it is necessary to consider and to visualize the years of development, from $2000 .{ }^{21}$

An individual and his/her environment, as the reflection of the ideology of selfmanagement, have been used for the creation of arguments which preceded the decision to create the new plan. In addition, we can adopt the same conclusion in the development of automobile traffic, which, in that period, depicted economic prosperity of a worker and his/her personal needs, and which was, in giving reasons for the revision, emphasised as a flaw of the old plan. In the aforementioned examples of materialisation of the self-management ideology we can notice the combination of the individual and the collective in the plan, which is present in a few segments. If we analyse the front-page of the plan, we can come to the same conclusion. To begin with, we have a house as the depiction of single family housing, and then the tendencies of development towards the collective housing which represents a reflection of the urbanisation of Belgrade in that period, then we have "Zastava 101" as both the reflection of prosperity at the state level and the peak of turning to an individual's personal needs (Fig. 1).

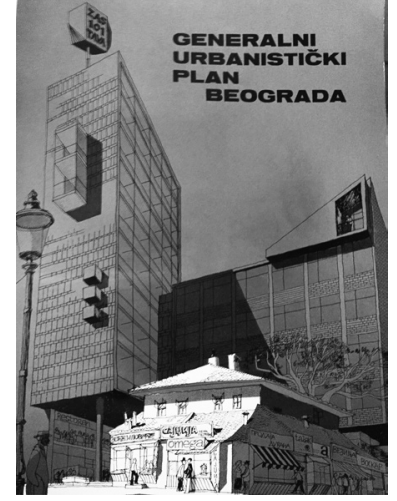

Fig. 1. Cover page of the Plan. General Urban Plan 1972.Beograd: Urban Planning Institute of Belgrade, 1972.

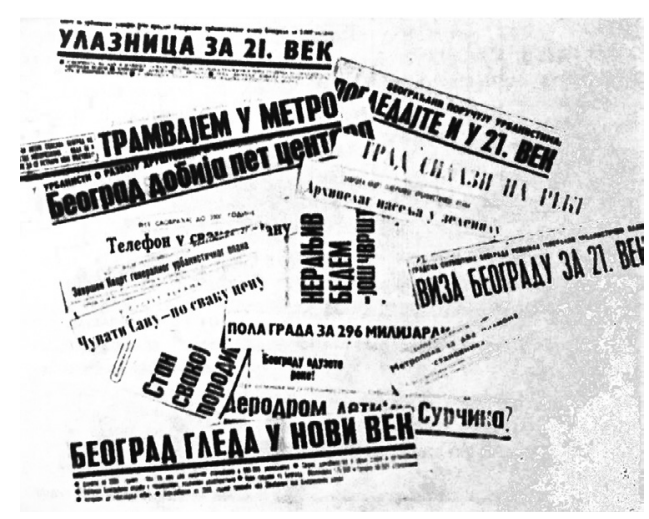

Fig. 2. Titles in the daily press. Belgrade, General Urban Plan 1972.Beograd: Urban Planning Institute of Belgrade, 1972 p.23. 
Instrumental Rationality in Service of

Constituting Ideology

The traffic study is of great importance for the formation of the plan discourse for various reasons. As stated in the plan: "The creation of the traffic study, simultaneously with the land use plan, represents a methodological innovation in Yugoslavia." 22 The decision on adopting new methodological approach was not only a result of the planer approach to planning, it was adopted after consulting the City Council and the Council for Urbanism, which shows us the significance of changing methodology, which was the question of politics in this case. Bringing in the team of experts from a prestigious American university, who have been given an important role in designing the methodology for plan creation, and the application of new mathematical models and the electronic computer techniques, demonstrate the inseparable role of ideological position of the planners from the Urban Planning Institute. We can find affirmation of this point of view if we look at the titles of daily newspapers from the period of plan creation (Fig. 2), where the presence of the plan in newspapers demonstrates the significance of planning as a discipline. Besides that, through emphasising the potential for traffic development, a tendency towards the new, different and globally recognisable Belgrade arises, along with the development of the attitude towards human environment. It was within the study of traffic and the attitude towards the environment that the largest number of analyses was carried out, including diagrams, methods and alternative solutions of spatial development on the whole (Fig.3). The materialisation of ideology is present in the development of traffic as a reflection of prosperity, modernisation at theindividual and general level, as well as in the attitude towards the preservation of environment, which is, again, related to the positioning of Yugoslavia and to the establishment of ecological movements which took place in that period at the global level.
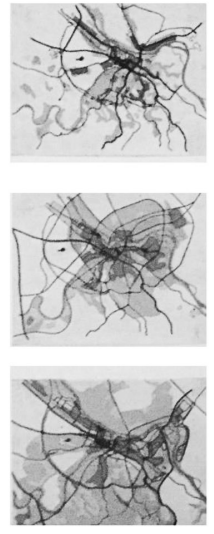

Fig. 3. Fifteen preliminary drawings (alternative solutions) of spatial development of Belgrade with the following legend: (yellow color: housing up to 100 inhabitants / ha; red color: housing over 100 inhabitants / ha; black color: town centers; gray color: economy; color: green; black lines: city motorways, urban roads, railways, metro and airport positions, blue color: water surfaces). Belgrade, General Urban Plan 1972.Beograd: Urban Planning Institute of Belgrade, 1972. p.104b. 


\section{Communication as the Pretence of Self-management}

Four basic steps were taken in the realisation of the procedures for public participation. The first one includes the forming of a professional multidisciplinary commission for the General Urban Plan, followed by the inclusion of various institutions, professional and scientific, through the creation of certain studies and surveys and the role of consultants. This was followed by the engagement of socio-political structures in a city and the inclusion of public opinion as the final step. According to the study The Participation of the Public in the Creation of Pre-drafts for the General Urban Plan (a Study), meetings were held in different political sections and municipalities and a number of presentations of the pre-drafts of the plan at the International Congress of Urban Planners in Belgrade in 1971, the International Symposium in Motovun in 1971, and the International Conference in Herceg Novi in 1971. The general report on the predraft of the plan was published in Serbian in 4,000 copies, while an abridged version was published in "The Communal News" in the print-run of 200,000 copies all people residing in Belgrade received. ${ }^{23}$ Besides that, the pre-draft prospect was printed in Russian, English, French and Serbian, and was given away to the participants of the aforementioned international conferences. In the Urban Planning Institute an exhibition of works was held within the phase of the plan pre-draft with a book of impressions in which visitors could write comments, remarks and suggestions regarding the plan.

If we take a look at the register of the participants, in the public discussion on the pre-draft of the general urban plan which is the part of the study, we can single out the majority of political sections within municipalities of Belgrade, city companies, professional societies and two institutions which are a part of the team responsible for making the General Urban Plan, the Urban Planning Council and the Professional Commission for the General Urban Plan, and finally, the citizens who have personally delivered the remarks to the Urban Planning Institute. Taking into consideration the number of remarks from the part of the aforementioned participants, the largest number of questions and opinions came exactly from the above-mentioned institutions which are a part of the team for plan creation. Apart from them, a large number of remarks came from the professional society, while only six out of 904 remarks were made by the citizens. 


\section{CONCLUSION}

Analysing the plan from the aspects of the theory of rational choice, we can see how the line of business creates rationality and builds its credibility, skillfully applying scientifically proven, innovative methods, the cooperation with international experts, a number of alternatives in order to show that the chosen one is the best, the formal consults with the public without their formal application in the plan, as well as the usage of the media for creating, i.e. supporting formal discourse. In the analysis of the plan from the aspect of communication theory, the participation of public, public opinion and communicating at different levels, from local to global recognition of public participation are notable in the shaping of discourse. By that, the processes of communication which participated in the realisation of the plan's legitimacy are visible again, i.e. communication served as an instrument for reaching certain goals, set by plan and realised in the pre-draft phase.

Self-government, in its intention to implement the democratic approach, failed to enable the mechanisms for decision-making and including the individual needs and interests of the citizens who are allegedly presented as decision-makers, which can be related to the Habermas's ideal. The "downside-up" approach in applying self-government and its connection to planning is problematic because it was carried out "upside-down" in practice, it was entirely centralised given that the state was the one that made plans, built, lives and evaluated, playing in that sense the role of a worker, a community member, and a selfgovernor who has a minor role in making decisions. With such an approach, the domination of the government in making decisions is achieved through the domination over institutions, which further shows their domination in shaping the discourse of the plan. Thus we can conclude that the plan also influences the further positioning of institutions and creating a vicious circle. This fact shows that planning cannot be separated from the social, i.e. political context and in that sense, the question whether rationality is the result of communication or a product of knowledge becomes unimportant, because it is ideology that builds the discourse of the plan. 
Aleksandar Kušić, “West(ern urbanism): a part of social fantasy space”, Serbian Architectural Journal, (2011): 226-252

Miloš Timotijević, Modernizacija balkanskog grada (1944-1989): Komparativna analiza razvoja Čačka i Blagoevgrada u epohi socijalizma. (Čačak: Narodni muzej, 2012)

Edvard Kardelj, Samoupravljanje u Jugoslaviji 1950-1976 (Beograd: Privredni pregled, 1977), 10. Ibid.

Borisav Džuverović, “Kultura u samoupravnom društvu”, Kultura , no.52, (1982): 176-185.

Edvard Kardelj, Pravci razvoja političkog sistema socijalističkog samoupravljanja(Beograd: Izdavački centar "Komunist", 1977), 90 Borisav Džuverović, "Kultura u samoupravnom društvu”, Kultura , no.52, (1982): 176-185. planning, Modernism, and Socialism in Belgrade.. (Pittsburgh: The University of Pittsburgh press, 2014), 213-242. 
Ibid.

Ibid.

Ernest Alexander, "Design in the decision making process", Policy sciences, no.14(June, 1982): 279292.

Bent Flyvbjerg, Rationality and Power. Prevod: Steven Sampson. (Chicago: The University of Chicago press, 1998)

Bent Flyvbjerg, "The dark side of planning: rationality and "realrationalitat" in Explorations in planning theory. (Rutgers: Centre for Urban Policy Research.1996)

Bent Flyvbjerg and Tom Richardson, "Planning and Foucault: in search of the dark side of planning theory"In Planning Futures: New Directions for Planning Theory (London and New York: Routledge, 2002), 44-62.

Ibid.

Michael Foucault, Discipline and Punish: the birth of the prison (New York: Vintage. 1979), 27.

Bent Flyvbjerg, "The dark side of planning: rationality and "realrationalitat" in Explorations in planning theory. (Rutgers: Centre for Urban Policy Research.1996)

Aleksandar Đorđević, Generalni urbanistički plan Beograda iz 1972 (Beograd: Urbanistički zavod Beograda, 1972)

Ibid.

Ibid.

Aleksandar Đorđević, Generalni urbanistički plan Beograda iz 1972 (Beograd: Urbanistički zavod Beograda, 1972)

Ibid. 
Alexander, Ernest, R.“ Rationality revisited: planning paradigms in a post-postmodernist perspective.“ Journal of Planning Education and Research, no.19 (spring 2000): 242-256

Džuverović, Borisav. „Kultura u samoupravnom društvu.“ Kultura no.52 (1982):176-185.

Flyvjerg, Bent. Rationality and Power. Prevod: Steven Sampson. Chicago: The University of Chicago press, 1998.

Flyvbjerg, Bent and Richardson, Tom. "Planning and Foucault: in search of the dark side of planning theory." In Planning Futures: New Directions for Planning Theory, edited by Philip Allmendinger and Mark Tewdwr-Jones, 44-62. London and New York: Routledge, 2002.

Flyvbjerg, Bent. ,,The dark side of planning: rationality and "realrationalitat". In Explorations in planning theory, edited by S. J. Mandelbaum, L. Mazza and R. W. Burchell. Rutgers: Centre for Urban Policy Research.1996.

Foucault, Michael. Discipline and Punish: the birth of the prison. New York: Vintage, 1979.

Kardelj, Edvard. Pravci razvoja političkog sistema socijalističkog samoupravljanja. Beograd: Izdavački centar "Komunist", 1977.

Kardelj, Edvard. Samoupravljanje u Jugoslaviji 1950-1976. Beograd: Privredni pregled, 1977.

Krstić, Branislav i Pajović, Dušan. Zakonodavstvo urbanizma, arhitekture, baštine, čovekove sredine $i$ prostornog uređenja. Beograd: Naučna knjiga, 1987.

Kušić Aleksandar. "West(ern urbanism): a part of social fantasy space." Serbian Architectural Journal, (2011):226-252.

Le Normand, Brigitte. Designing Tito's Capital: Urban planning, Modernism, and Socialism in Belgrade. Modernity redefined - the master plan 1972. Pittsburgh: The University of Pittsburgh press, 2014.

Timotijević, Miloš. Modernizacija balkanskog grada (1944-1989) : Komparativna analiza razvoja Čačka i Blagoevgrada u epohi socijalizma. Čačak: Narodni muzej, 2012.

Đorđević, Aleksandar. Generalni urbanistički plan Beograda iz 1972. Beograd: Urbanistički zavod Beograda, 1972.

Učešće javnosti u izradi nacrta generalnog urbanističkog plana Beograda. Beograd: Urbanistički zavod Beograda, 1971. 
